\title{
Microtopographic control on the ground thermal regime in ice wedge polygons
}

\author{
Charles J. Abolt ${ }^{1,2}$, Michael H. Young ${ }^{2}$, Adam L. Atchley ${ }^{3}$, and Dylan R. Harp ${ }^{3}$ \\ ${ }^{1}$ Department of Geological Sciences, The University of Texas at Austin, Austin, TX, USA \\ ${ }^{2}$ Bureau of Economic Geology, The University of Texas at Austin, Austin, TX, USA \\ ${ }^{3}$ Earth and Environmental Sciences Division, Los Alamos National Laboratory, Los Alamos, NM, USA
}

Correspondence: Charles J. Abolt (chuck.abolt@beg.utexas.edu)

Received: 3 January 2018 - Discussion started: 12 January 2018

Revised: 22 May 2018 - Accepted: 24 May 2018 - Published: 11 June 2018

\begin{abstract}
The goal of this research is to constrain the influence of ice wedge polygon microtopography on near-surface ground temperatures. Ice wedge polygon microtopography is prone to rapid deformation in a changing climate, and cracking in the ice wedge depends on thermal conditions at the top of the permafrost; therefore, feedbacks between microtopography and ground temperature can shed light on the potential for future ice wedge cracking in the Arctic. We first report on a year of sub-daily ground temperature observations at 5 depths and 9 locations throughout a cluster of lowcentered polygons near Prudhoe Bay, Alaska, and demonstrate that the rims become the coldest zone of the polygon during winter, due to thinner snowpack. We then calibrate a polygon-scale numerical model of coupled thermal and hydrologic processes against this dataset, achieving an RMSE of less than $1.1^{\circ} \mathrm{C}$ between observed and simulated ground temperature. Finally, we conduct a sensitivity analysis of the model by systematically manipulating the height of the rims and the depth of the troughs and tracking the effects on ice wedge temperature. The results indicate that winter temperatures in the ice wedge are sensitive to both rim height and trough depth, but more sensitive to rim height. Rims act as preferential outlets of subsurface heat; increasing rim size decreases winter temperatures in the ice wedge. Deeper troughs lead to increased snow entrapment, promoting insulation of the ice wedge. The potential for ice wedge cracking is therefore reduced if rims are destroyed or if troughs subside, due to warmer conditions in the ice wedge. These findings can help explain the origins of secondary ice wedges in modern and ancient polygons. The findings also imply that the potential for re-establishing rims in modern thermokarst-affected
\end{abstract}

terrain will be limited by reduced cracking activity in the ice wedges, even if regional air temperatures stabilize.

\section{Introduction}

It has long been understood that the formation of ice wedge polygons is intimately linked with thermal contraction ground stresses (Leffingwell, 1915; Lachenbruch, 1962; Mackay, 2000). However, changes to the near surface thermal regime as polygon microtopography develops are poorly constrained. Across the continuous permafrost zone, winter ground temperatures below $-10^{\circ} \mathrm{C}$ commonly drive the opening of a network of cracks, $\sim 4-5 \mathrm{~m}$ deep, that bound polygonal regions of soil, $10-30 \mathrm{~m}$ in diameter. Over timescales of centuries to millennia, repeated cracking and infilling with ice in the same locations produces wedgeshaped bodies of ice at the top of the permafrost, up to $5 \mathrm{~m}$ wide (Kanevskiy et al., 2013). Particularly in coastal regions of the Arctic, the slow growth of ice wedges results in subtle but distinctive surface topography, as pressure between the wedge and the adjacent ground creates rims of raised soil at the perimeters of the polygons. Although only on the scale of decimeters, this microtopography profoundly influences tundra hydrology (Liljedahl et al., 2012, 2016), and may exert equally strong controls on microbial conversion of soil organic carbon into carbon dioxide and methane (Zona et al., 2011; Wainwright et al., 2017). Polygon microtopography also controls depth variation in the winter snowpack, which accumulates preferentially in low zones, such as the trough space between polygons (Mackay, 1993, 2000; 
Morse and Burn, 2014; Wainwright et al., 2015). It is well known that snow accumulation in periglacial terrain strongly controls winter ground temperatures, by providing insulation from the atmosphere (e.g., Mackay and MacKay, 1974; Goodrich, 1982). Moreover, it has been widely observed that changes to polygon microtopography have accelerated in the past three decades, as rising air temperatures have increasingly driven the subsidence of troughs and the destruction of rims (Jorgenson et al., 2006; Raynolds et al., 2014; Liljedahl et al., 2016). However, feedbacks between microtopographic change and the thermal regime of the ice wedge, which directly control the likelihood of sustained ice wedge cracking in the future, are incompletely understood.

In this paper, we quantify the relationship between the microtopography of ice wedge polygons and subsurface temperatures, using a combination of field observations and numerical modeling. We first analyze a high-resolution record of ground temperature in key locations beneath a lowcentered polygon near Prudhoe Bay, Alaska, and use the observational data to calibrate a numerical model of coupled thermal and hydrologic processes at the polygon scale. We then conduct a sensitivity analysis to determine the influence of two topographic attributes, rim height and trough depth, on winter temperatures in the ice wedges. To our knowledge, our analysis is the first to quantitatively estimate influences on ground temperature associated with these two variables, which are difficult to control in field experiments and prone to rapid variation as polygons develop and respond to a changing climate (Jorgenson et al., 2006; Raynolds et al., 2014; Liljedahl et al., 2016). The results shed light on feedbacks that will determine the sustainability of ice wedge cracking in the near future, as warming air temperatures drive rapid surface deformation in polygonal terrain. The results are also relevant to understanding of processes associated with historical development of ice wedge polygons, including the formation of "secondary" ice wedges, or comparatively young wedges that subdivide older polygons, observed in modern and ancient systems (Burn and O'Neill, 2015).

\section{Background}

A substantial amount of research has explored interactions between ground temperatures and ice wedge cracking. The earliest, and still most rigorous, mechanical analysis was conducted by Lachenbruch $(1962,1966)$, who concluded that the probability of a cracking event is determined by two criteria: whether the ground temperature cools below a variable threshold near $-10^{\circ} \mathrm{C}$, and whether the rate of cooling is sufficient. These conditions are most crucial at the top of the permafrost, where most ice wedge cracks originate (Mackay, 1984). Recently, a number of investigations have used electronic temperature sensors to more tightly constrain thermal conditions at the time of cracking at field sites across the Arctic (e.g., Mackay, 1993; Allard and Kasper, 1998; Chris- tiansen, 2005; Fortier and Allard, 2005; Kokelj et al., 2007, O'Neill and Christiansen, 2018). Although heterogeneity exists between sites, it has been generalized that ice wedge cracking is most favorable when ground temperature at the top of the permafrost drops below $-13^{\circ} \mathrm{C}$, and the rate of cooling exceeds $0.1{ }^{\circ} \mathrm{C} \mathrm{day}^{-1}$ for two days or more (Morse and Burn, 2013; Kokelj et al., 2014).

In contrast to research on ice wedge cracking, relatively few investigations have explored systematic variation in ground temperatures associated with polygon microtopography. In particular, few datasets have been published that monitor ground temperature beneath distinct zones of a polygon in the same season. Nonetheless, one consistently observed trend is that the rims of a low-centered polygon tend to become several degrees colder in winter than the center or troughs (Mackay, 1993; Christiansen, 2005; Morse and Burn, 2014; Atchley et al., 2015). This effect is attributed to the thinner snowpack on top of the rims, as wind-driven redistribution of snow enhances accumulation in microtopographic lows. Consistent with these observations, previous conceptual models of the thermal regime of the active layer in ice wedge polygons have incorporated the idea that cooling is enhanced in raised zones, such as rims (Christiansen, 2005; Morse and Burn, 2014) and impeded in low ones (Gamon et al., 2012). However, the strength of these effects, and interactions between them at the polygon scale, remain unclear. For example, if the influence of enhanced cooling in the rims of a low-centered polygon extends to adjacent regions of the subsurface, it seems likely that the gradual development of rims would promote colder temperatures in the ice wedge. This effect would represent a positive feedback on development of low-centered polygons, because colder temperatures favor cracking and the expansion of the ice wedge. In contrast, it has also been suggested that development of relief in the rims drives precisely the opposite effect, by increasing snow entrapment in the troughs, thereby enhancing insulation of the ice wedges (Lachenbruch, 1966).

Improved understanding of interactions between microtopography, snow depth, and ground temperature is needed to resolve these conflicting conceptual models, because feedbacks between these variables may have important ramifications for ice wedge cracking at all stages of polygon development. For example, it was argued recently that the presence of secondary ice wedges, or young wedges that subdivide older polygons, results from deactivation of the older primary network due to increased snow entrapment in the troughs, either as the rims grow or the trough itself subsides (Morse and Burn, 2013; Burn and O'Neill, 2015). This conceptual model has important implications for interpretation of both modern wedges and Pleistocene-aged ice wedge casts, and is supported by observations that secondary ice wedges are rare in erosive environments (such as hillslopes) or depositional settings (such as river deltas), where polygon microtopography tends to be muted or non-existent (Mackay, 1990, 1995). However, it competes with a second hypothesis, that 
secondary wedges are instead reflections of infrequent severe winter conditions, during which cracking in the primary network alone is insufficient to relieve thermal contraction stresses (Dostovalov and Popov, 1966). This latter hypothesis was supported by a numerical model of ground cracking under an imposed tensile stress (Plug and Werner, 2002), but the model was criticized for failing to represent heterogeneity in the subsurface stress field associated with microtopography (Burn, 2004).

Feedbacks between microtopography and subsurface temperatures are likewise relevant to conceptualizing modern thermokarst development in the Arctic, as the changing form of polygons may influence the probability of sustained cracking in degraded ice wedges. As permafrost degradation has accelerated in recent decades (Walker et al., 1987; Osterkamp and Romanovsky, 1996; Jorgenson et al., 2006; Raynolds et al., 2014; Liljedahl et al., 2016), thaw in the upper portions of ice wedges has increasingly triggered trough subsidence and the destruction of low-centered polygon rims, creating high-centered polygons. Raynolds et al. (2014) condensed years of field observations into a conceptual model of the process, suggesting that, while the degradation of lowcentered polygon rims has historically been a reversible process, much recent thermokarst has proceeded to irreversible extents, due to the destruction of an ice-rich "intermediate" or "transition layer" at the top of the permafrost, which normally buffers deeper zones from thaw. Presumably, the permanence (or reversibility) of modern thermokarst will also be determined by the potential for future ice wedge cracking, which will be necessary to re-establish polygon rims. Understanding of the potential for ice wedges in degraded troughs to cool to temperatures suitable for cracking is therefore important for predicting the duration of changes to landscapescale processes associated with high-centered polygon development, such as increased runoff, decreased evapotranspiration (Liljedahl et al., 2012, 2016), and increased emissions of carbon dioxide (Wainwright et al., 2015).

\section{Methods}

\subsection{Study area and data acquisition}

The study site is within a low-centered polygon network approximately $40 \mathrm{~km}$ south of Prudhoe Bay and $1 \mathrm{~km}$ west of the Dalton Highway in Alaska's North Slope Borough (Fig. 1a). The surficial geology of the region is dominated by fluvial and marine-fluvial silty sands, associated with streams flowing north from the Brooks Range (Jorgenson and Shur, 2007; Raynolds et al., 2014). These deposits are capped with approximately $2 \mathrm{~m}$ of Pleistocene-aged aeolian silt, which grades upward into a surface mantle of peat (Everett, 1980). Active layer thickness varies from 70 to $90 \mathrm{~cm}$, extending into the aeolian silt layer. Vegetation at the site is typical of the region, and consists almost exclusively of low- (a)

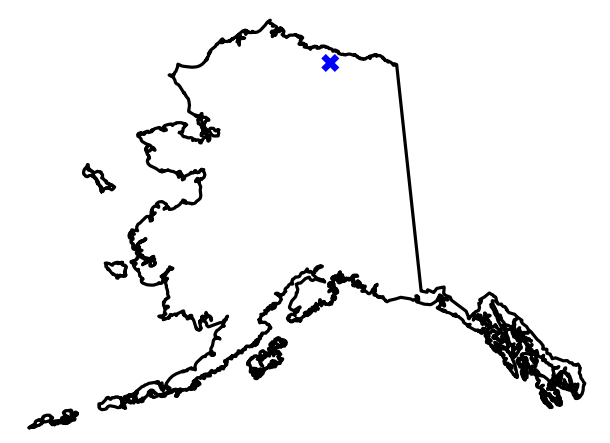

(b)

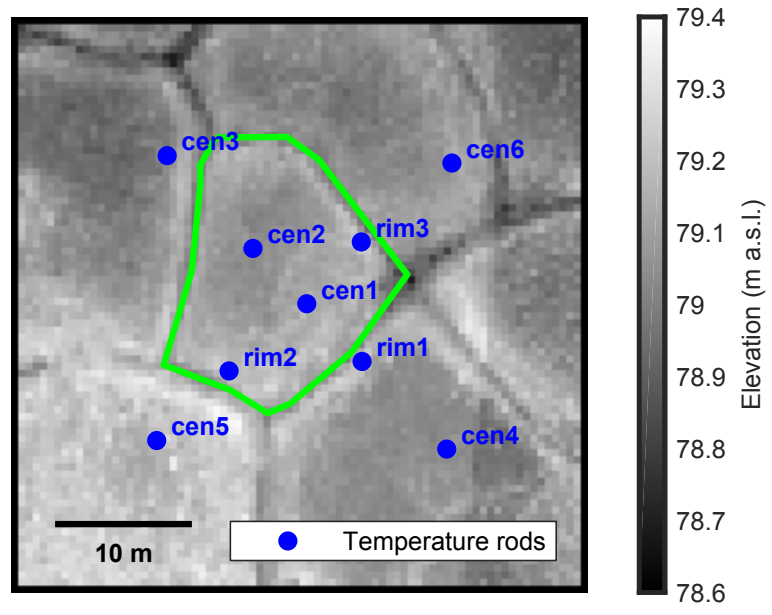

Figure 1. Location of field site (a) and $50 \mathrm{~cm}$ resolution lidar DEM with ice wedge polygon extent and temperature sensor rod locations indicated (b).

lying sedges and grasses. Mean annual air temperature from 2000-2015 was $-8.9^{\circ} \mathrm{C}$, as estimated by Noah Land Surface Model output from NASA's Global Land Data Assimilation System (GLDAS), which provides estimates of global weather conditions from year 2000 to the present at a spatial resolution of $0.25^{\circ}$ and a temporal resolution of $3 \mathrm{~h}$ (Rodell et al., 2004).

The microtopography of the studied polygon (outlined in green) is represented in a $50 \mathrm{~cm}$ resolution lidar digital elevation model (DEM) (Fig. 1b). Like many low-centered polygons south of Prudhoe Bay, the polygon has modest relief compared with polygons elsewhere in the Arctic, with surface elevations ranging from $\sim 78.8$ to $79.2 \mathrm{~m}$ above sea level. The relatively low rims and the presence of standing water at the eastern vertex of the polygon suggest that some ice wedge degradation has occurred in recent decades, as documented at nearby sites (Raynolds et al., 2014).

Field work was conducted in late July 2014 and early September 2015. During the first visit, temperature "sensor rods" (Alpha Mach, Sainte-Julie, Québec, Canada) were installed across the polygon (locations shown as blue dots in Fig. 1b). Each rod was equipped with thermistors embedded in a waterproof plastic pipe, and driven into the active layer 


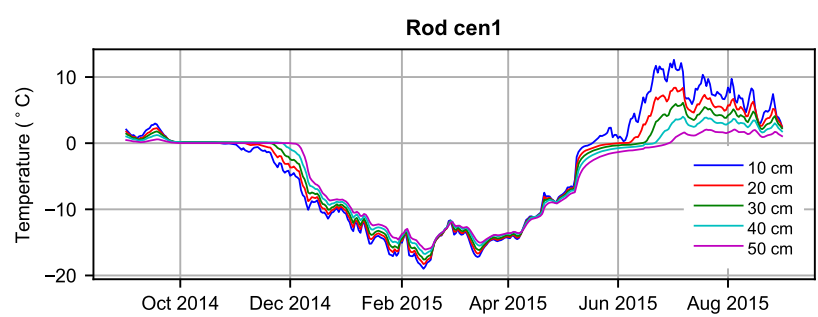

Figure 2. Sample of observed temperature data from sensor rod cen1.

to observe temperature at depths of 10,20,30,40 and $50 \mathrm{~cm}$. Each rod contained an onboard power source and data logger programmed to record temperature every $3 \mathrm{~h}$. The temperature resolution of the sensors was $0.125^{\circ} \mathrm{C}$, and their accuracy was estimated by the manufacturer at $\pm 0.5^{\circ} \mathrm{C}$. Sensor rods were installed into a mix of higher-elevation rim sites, and lower-elevation sites from the polygon interiors. Rods were removed and data were downloaded in September 2015. A sample from rod cen1 (Fig. 2) displays temperature data from September 2014 through August 2015. Data from all rods are included in the Supplement (Fig. S1).

In addition to sensor rod installation, soil cores were collected in 2014 and subsequently analyzed for hydraulic and thermal properties. Soil cores were collected in both the center and the rims, at depths varying from ground surface to $19 \mathrm{~cm}$. Soil cores below $19 \mathrm{~cm}$ could not be collected due to a high water table. Laboratory analyses of the soil cores, described in the Supplement (Sect. S1, Table S1), informed the parameterization of our numerical model.

\subsection{Statistical analysis of observational data}

Prior to constructing a numerical model, data from the sensor rods were analyzed to understand differences in the subsurface thermal regime between the rims and other areas of the polygon. The seasonality of these differences was also evaluated to determine the potential relationship with snow cover. A set of one-tailed rank sum tests was used to evaluate the hypothesis that minimum winter temperatures in the rims $(n=3)$ are lower than in the polygon centers $(n=6)$ at all observed depths, and to determine whether the autumn freezing curtain is shorter in the rims than elsewhere. Freezing curtain duration was defined at each sensor as the length of time that ground temperature remained between -0.5 and $0.5^{\circ} \mathrm{C}$, or approximately zero (within the accuracy of the sensors), due to the release of latent heat as soil water freezes. We expected that rims would experience shorter freezing curtains, due to enhanced cooling and decreased soil water content. Finally, to analyze seasonality, the rank sum test was used to determine whether mean monthly temperatures are coldest in the rims, each month from September 2014 through August 2015. We expected that rims would only be colder than the centers during months with significant snow cover.

\subsection{Overview of the Advanced Terrestrial Simulator}

Our numerical model used the Advanced Terrestrial Simulator (ATS, version 0.86), a code developed by the United States Department of Energy within the Amanzi framework (Moulton et al., 2011) to simulate surface and nearsurface thermal hydrology in variably saturated media (https: //github.com/amanzi/ats). ATS uses a multi-physics process management tool called Arcos (Coon et al., 2015) to allow for flexibility in coupling self-contained models for each component of the physical system (e.g., the subsurface mass balance and the surface energy balance). ATS was chosen for its record of successful application to permafrost terrain (Atchley et al., 2015, 2016; Harp et al., 2016; Sjoberg et al., 2016; Schuh et al., 2017; Jan et al., 2018), and for its rich collection of features tailored to simulating hydrologic processes in cold environments. One component of ATS that is particularly useful for our study is a unique module that emulates wind-blown redistribution of snow across topography using a diffusion-wave equation, taking the same mathematical form as the Mannings equation. This causes snow accumulation to vary inversely with elevation, by leveling the top of the snowpack into a flat surface. In the present implementation, we coupled the subsurface conservation of mass and energy with a surface energy balance model, which was driven by meteorological data and allowed for accumulation of liquid water, ice, and snow at the surface. An overview of the partial differential equations governing surface and subsurface processes is presented in Painter et al. (2016). A detailed explanation of the surface energy balance, including description of a snowpack aging model used to estimate changing snow thermal conductivity and albedo throughout the winter, is presented in Atchley et al. (2015).

\subsection{Model construction, calibration and sensitivity analysis}

Construction and calibration of the numerical model followed the workflow described by Atchley et al. (2015), with each model run comprising three computer simulations. In the first simulation, a water table was established near the surface in isothermal conditions by defining a constantpressure (Dirichlet) boundary condition at the bottom of the domain. In the second simulation, permafrost conditions were established by adding a constant-temperature boundary condition at the bottom ( $50 \mathrm{~m}$ depth), allowing the soil column to freeze from below. In the third simulation, the surface energy balance was introduced, employing meteorological data to define transient thermal and hydraulic boundary conditions at the top of the domain.

Due to the availability of field samples used to estimate soil physical properties, and in an effort to avoid over-fitting 


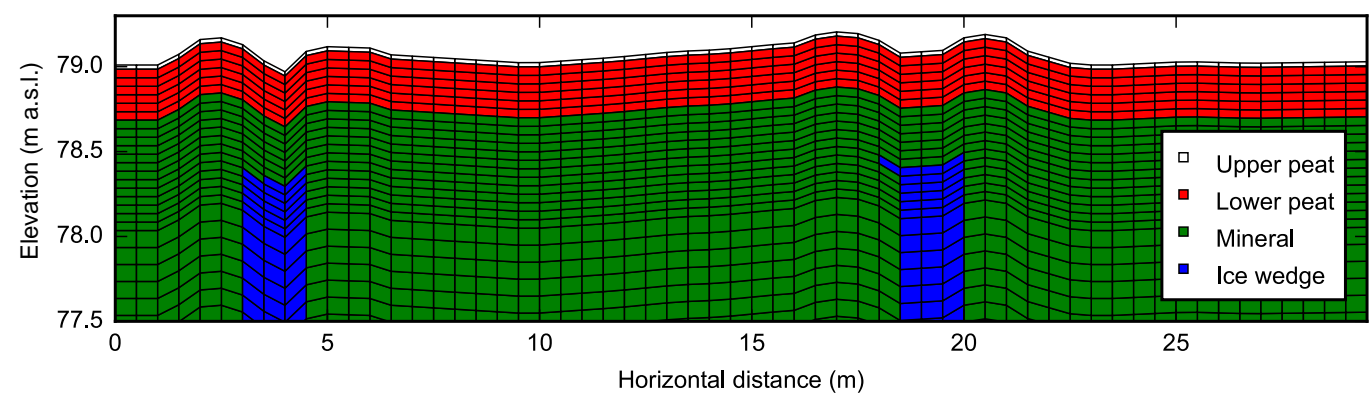

Figure 3. Schematic of the near-surface portion of the 2-D mesh of the field site (vertical exaggeration $=4$ ). Mesh extends to $50 \mathrm{~m}$ below the ground surface.

Table 1. Ground physical (hydraulic and thermal) properties used in model.

\begin{tabular}{|c|c|c|c|c|c|c|c|c|}
\hline $\begin{array}{l}\text { Ground } \\
\text { material }\end{array}$ & Porosity & $\begin{array}{r}\text { Residual } \\
\text { water } \\
\text { content }\end{array}$ & $\begin{array}{r}\text { Van } \\
\text { Genuchten } \\
\text { parameter }\end{array}$ & $\begin{array}{r}\text { Van } \\
\text { Genuchten } \\
\text { parameter }\end{array}$ & $\begin{array}{r}\text { Intrinsic } \\
\text { permeability }\end{array}$ & $\begin{array}{r}\text { Saturated } \\
\text { (thawed) thermal } \\
\text { conductivity }\end{array}$ & $\begin{array}{r}\text { Saturated } \\
\text { (frozen) thermal } \\
\text { conductivity }\end{array}$ & $\begin{array}{l}\text { Dry thermal } \\
\text { conductivity }\end{array}$ \\
\hline & $\begin{array}{r}\phi \\
\left(\mathrm{m}^{3} \mathrm{~m}^{-3}\right)\end{array}$ & $\begin{array}{r}\theta_{\mathrm{r}} \\
\left(\mathrm{m}^{3} \mathrm{~m}^{-3}\right)\end{array}$ & $\begin{array}{r}\alpha \\
\left(\mathrm{cm}^{-1}\right)\end{array}$ & $\begin{array}{r}m \\
\text { (unitless) }\end{array}$ & $\begin{array}{r}k \\
\left(\mathrm{~m}^{2}\right)\end{array}$ & $\left(\begin{array}{r}\lambda_{\mathrm{s}} \\
\left(\mathrm{W} \mathrm{m}^{-1} \mathrm{~K}^{-1}\right)\end{array}\right.$ & $\left(\mathrm{W} \mathrm{m}^{-1} \mathrm{~K}^{-1}\right)$ & $\left(\begin{array}{r}\lambda_{u} \\
\left(\mathrm{~W} \mathrm{~m}^{-1} \mathrm{~K}^{-1}\right)\end{array}\right.$ \\
\hline Upper peat & 0.80 & 0.08 & 0.02 & 0.30 & $5 \times 10^{-11}$ & 0.6 & 1.8 & 0.10 \\
\hline Lower peat & 0.70 & 0.07 & 0.02 & 0.40 & $2 \times 10^{-12}$ & 0.75 & 1.9 & 0.12 \\
\hline Mineral soil & 0.50 & 0.10 & $5.4 \times 10^{-4}$ & 0.19 & $2 \times 10^{-13}$ & 1.0 & 2.0 & 0.29 \\
\hline Ice wedge & 0.99 & 0.00 & $5.4 \times 10^{-4}$ & 0.19 & 0.0 & 0.59 & 2.2 & N/A \\
\hline
\end{tabular}

the model, calibration focused solely on snow pack parameters. As described in the Supplement (Sect. S2), the calibrated parameters included the thermal conductivity of fresh snow, the snow redistribution coefficient used to transport snowpack across variable topography and a snowfall multiplier used to correct for under-reporting in our meteorological data. For calibration, a 2-D domain was developed using topography from the lidar DEM, which included four ground materials (Fig. 3). The domain extended laterally from approximately $1 \mathrm{~m}$ northwest of rod cen 3 to $2 \mathrm{~m}$ southeast of rod cen4, intersecting five sensor rods in different microtopographic positions. The bottom boundary temperature was set at $-6^{\circ} \mathrm{C}$, characteristic of nearby borehole observations (Romanovsky et al., 2009). To approximate the gradation of surficial peat into mineral soil at our site, the upper $2.5 \mathrm{~cm}$ of the soil column was defined as unconsolidated peat, and the next $30 \mathrm{~cm}$ as more tightly compacted peat. Soil hydraulic and thermal parameters for these upper layers were assigned using laboratory estimates from the core samples (See Supplement for methods (Sect. S2) and results (Table S1)). The lower soil layers were modeled as mineral soils, to which the ATS default parameters, characteristic of a silty sand, were applied. Ice wedges were included beneath the troughs at a depth of $80 \mathrm{~cm}$, consistent with an active layer survey conducted in September 2015. Physical parameters for all ground materials used in the model are summarized in Table 1 .
Meteorological variables used to drive simulations included air temperature, wind speed, incident shortwave radiation, longwave radiation, relative humidity, rainfall and snowfall. Time series of each variable were derived from the output of the Noah Land Surface Model as distributed by GLDAS (Rodell et al., 2004). Meteorological data were extracted from the pixel centered at $69.875^{\circ} \mathrm{N}, 148.875^{\circ} \mathrm{W}$ (approximately $5 \mathrm{~km}$ from our field site) for the time period from 1 September 2010-31 August 2015, and each variable was averaged into daily means. The first four years of this period were used as spin-up, and the fifth year was used to compare simulated against observed temperatures.

After obtaining a suitable calibration using field site microtopography, a sensitivity analysis was conducted by repeating simulations with hydraulic and thermal parameters held constant, but with the height of the rims and the depth of the troughs being systematically altered. Following each simulation, winter temperatures were extracted from 2014 to 2015 from the uppermost cell at the center of the southeast (right) ice wedge, and compared to the criteria identified by Morse and Burn (2013) that favor ice wedge cracking. Simulations scanned through six different rim heights, varying from -10 to $+15 \mathrm{~cm}$ in increments of $5 \mathrm{~cm}$; and five different trough depths, varying from unchanged to $40 \mathrm{~cm}$ deeper, in increments of $10 \mathrm{~cm}$. These ranges were chosen to recreate the variability observed near our field site and to match recent documentation of troughs impacted to various degrees by ice wedge degradation (Jorgenson et al., 2006). 
Table 2. Minimum observed temperature $\left({ }^{\circ} \mathrm{C}\right)$ at each sensor rod and depth $(\mathrm{cm})$.

\begin{tabular}{lrrrrrrrrrrr}
\hline Depth & cen1 & cen2 & cen3 & cen4 & cen5 & cen6 & rim1 & rim2 & rim3 & Center median & Rim median \\
\hline 10 & -19.0 & -17.7 & -16.1 & -16.0 & -18.0 & -19.9 & -21.1 & -19.8 & -22.5 & -17.8 & -21.1 \\
20 & -18.3 & -19.1 & -15.7 & -15.1 & -17.2 & -19.2 & -19.9 & -18.4 & -20.8 & -17.1 & -19.7 \\
30 & -17.7 & -16.4 & -15.3 & -14.6 & -16.5 & -18.3 & -19.0 & -18.0 & -19.7 & -16.4 & -19.0 \\
40 & -16.8 & -15.6 & -14.3 & -14.0 & -15.7 & -17.6 & -18.0 & -17.2 & -18.7 & -15.7 & -18.0 \\
50 & -16.1 & -15.1 & -13.8 & -13.5 & -15.0 & -16.4 & -17.3 & -16.5 & -18.0 & -15.0 & -17.3 \\
\hline
\end{tabular}
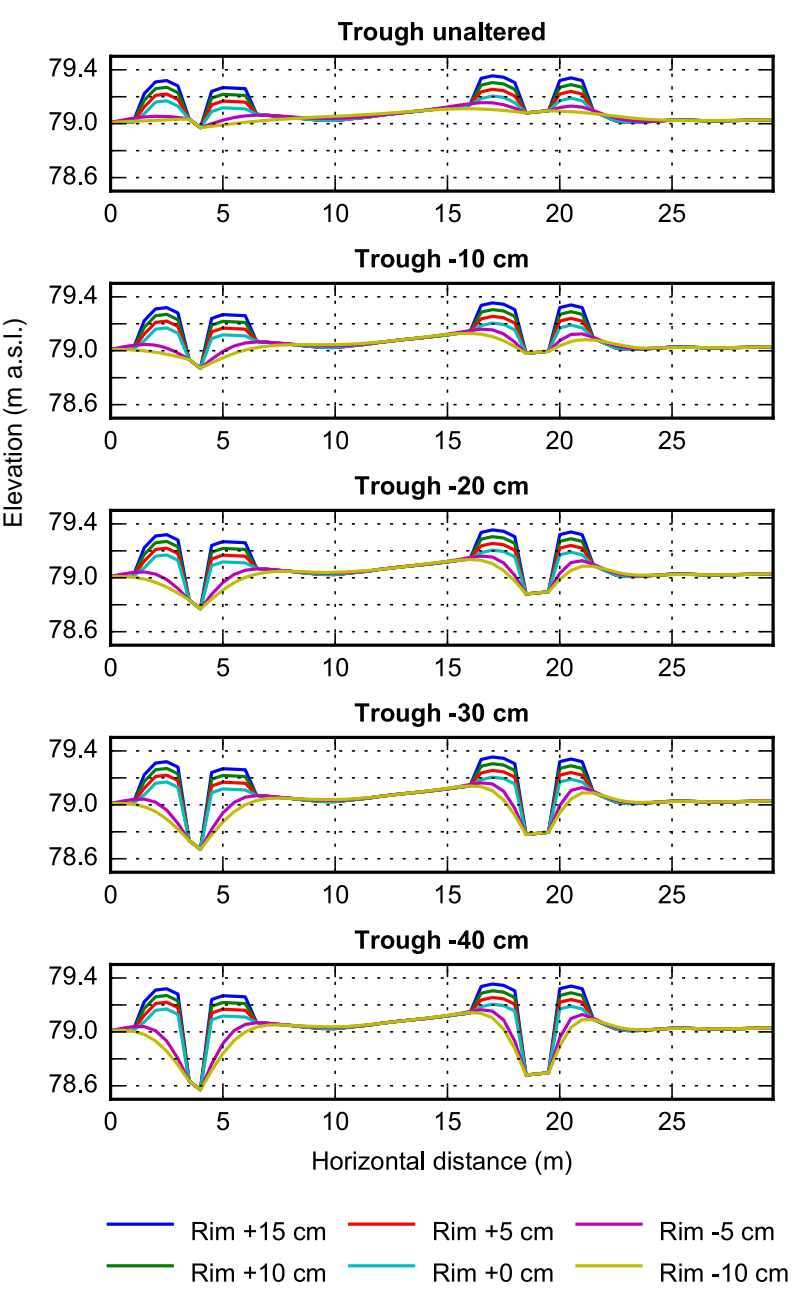

Figure 4. Schematic illustrating the range of topographic conditions explored in the sensitivity analysis (vertical exaggeration $=6$ ).

The ensemble of topographies for our analysis (Fig. 4) was created by altering the original mesh used to represent field site topography. When either trough depth or rim height was increased, the elevation of every rim or trough node was directly reassigned. Abolt et al. (2017) showed that the progression of polygonal topography from low-centered to highcentered form is closely approximated by the linear hillslope diffusion equation; therefore, when relief was reduced in the rims, a linear diffusion operator was applied to all non-trough nodes until the elevation of the southeast rim decreased by the desired amount. This procedure reproduced the topography of a high-centered polygon that is expected to develop as the rims of a low-centered polygon degrade.

\section{Results}

\subsection{Statistical analysis of observational data}

Minimum winter temperatures (Table 2) and freezing curtain durations (Table 3) observed among all sensor rods showed considerable variability, with temperatures in the rims becoming colder and falling below $0^{\circ} \mathrm{C}$ sooner than those in the centers. The results of the rank sum tests (Table 4) confirm that the difference between minimum winter temperature in the rims and in the centers is significant at all depths ( $p<0.025$, indicating a low probability that variations could be explained by random processes), with median differences varying from $3.2^{\circ} \mathrm{C}$ at $10 \mathrm{~cm}$ to $2.3^{\circ} \mathrm{C}$ at $50 \mathrm{~cm}$ depth. Similarly, freezing curtains are shorter in the rims than the centers at all observed depths $(p<0.025)$, the median difference being approximately 10 days.

The results of the rank sum tests, evaluating the hypothesis that rims experience mean monthly temperatures colder than the centers, reveal a stark seasonal pattern in which rims are significantly colder than the center $(p<0.1)$ only during the winter (Fig. 5). The difference first becomes significant at a depth of $10 \mathrm{~cm}$ in October, but requires an additional two months to become significant at a depth of $50 \mathrm{~cm}$. Rims remain significantly colder than centers through the month of March, after which there is no significant difference through the period of observation.

\subsection{Model calibration}

Results from the model calibration indicate that the bestperforming snowfall multiplier was 1.7. Using this value, maximum snow depth in the center of the polygon during the winter of 2014-2015 was approximately $45 \mathrm{~cm}$, comparing well with ground observations from SNOTEL stations at Deadhorse and Sagwon (approximately $40 \mathrm{~km}$ north and $40 \mathrm{~km}$ south of the study site, with maximum depths of 53 and $58 \mathrm{~cm}$, respectively; data available at https://www. 
Table 3. Freezing curtain duration (days) at each sensor rod and depth (cm).

\begin{tabular}{lccccccccccc}
\hline Depth & cen1 & cen2 & cen3 & cen4 & cen5 & cen6 & rim1 & rim2 & rim3 & Center median & Rim median \\
\hline 10 & 37.5 & 41.6 & 42.9 & 38.5 & 38.5 & 37.6 & 29.5 & 29.6 & 28.3 & 38.5 & 29.5 \\
20 & 54.3 & 57.1 & 58.0 & 34.6 & 49.8 & 52.8 & 38.8 & 41.9 & 39.5 & 54.4 & 39.5 \\
30 & 59.8 & 64.1 & 65.0 & 62.1 & 57.1 & 59.4 & 52.5 & 57.0 & 50.8 & 60.9 & 52.5 \\
40 & 68.6 & 72.0 & 74.1 & 71.5 & 61.5 & 64.9 & 58.4 & 67.9 & 58.1 & 68.6 & 58.4 \\
50 & 77.1 & 77.4 & 80.8 & 81.8 & 68.5 & 75.6 & 65.0 & 68.0 & 64.1 & 77.3 & 65.0 \\
\hline
\end{tabular}

Table 4. Rank sum test results ( $p$-values) for two hypotheses.

\begin{tabular}{lrrrrr}
\hline Hypothesis & \multicolumn{4}{c}{ Depth $(\mathrm{cm})$} \\
\cline { 2 - 6 } & 10 & 20 & 30 & 40 & 50 \\
\hline Rims have colder minimum temperatures than centers & 0.024 & 0.024 & 0.024 & 0.024 & 0.012 \\
Rims have shorter freezing curtains than centers & 0.012 & 0.012 & 0.012 & 0.024 & 0.012 \\
\hline
\end{tabular}

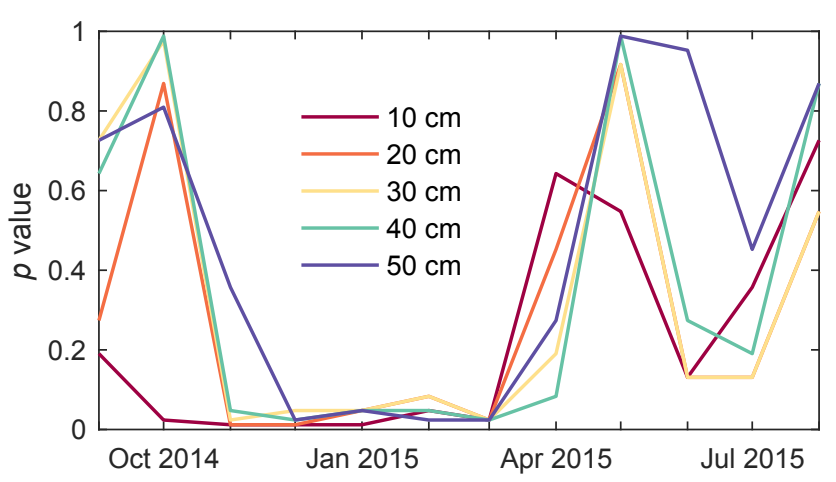

Figure 5. Results of the rank sum test, evaluating whether mean monthly temperatures are colder in the rims than in the centers.

wcc.nrcs.usda.gov/snow/). The optimal thermal conductivity for freshly fallen snow was $0.021 \mathrm{~W} \mathrm{~m}^{-1} \mathrm{~K}^{-1}$, which is within the range of recently published field measurements (Riche and Scheebeli, 2013; Domine et al., 2016). Additionally, the snow redistribution coefficient was reduced $60 \%$ from the ATS default value, effectively increasing the speed with which the snowpack developed a level surface in winter. Using these parameters, RMSE between simulated and observed daily temperature from the year of observation, incorporating all 25 sensors embedded in the 2-D transect (5 thermistors in each of 5 sensor rods), was approximately $1.0^{\circ} \mathrm{C}$. RMSE at individual rods varied from $\sim 1.4^{\circ} \mathrm{C}$ at rod cen 4 to $\sim 0.7^{\circ} \mathrm{C}$ at rod cen3. Plots comparing simulated and observed ground temperature at rods cen 1 and rim 1 demonstrate a close visual match (Fig. 6). A snapshot of simulated ground temperature and snowpack on 24 December 2014 (Fig. 7) clearly illustrates zonation in the ground thermal regime, whereby the rims become the coldest zone of the polygon.
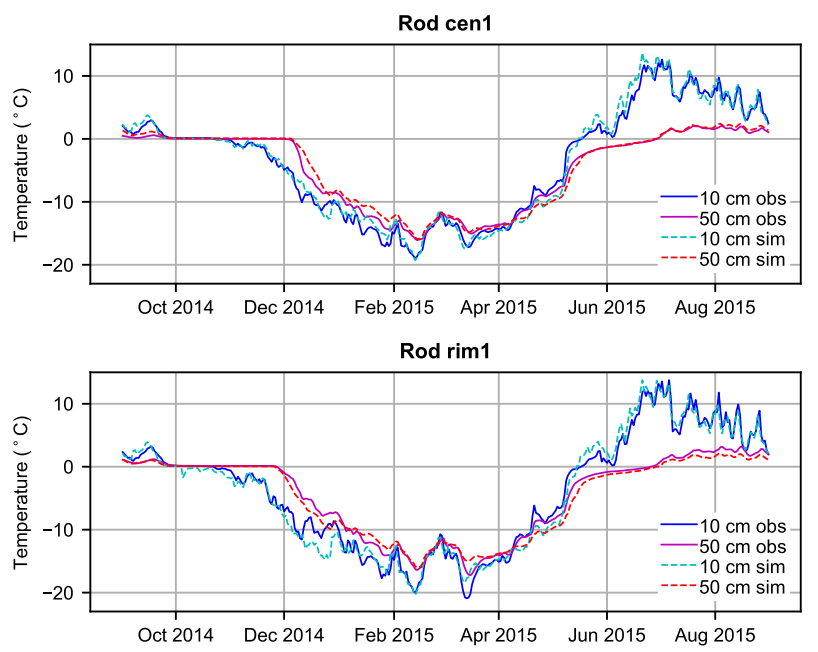

Figure 6. Observed and simulated ground temperature from calibrated 2-D simulation, at temperature sensor rods cen1 and rim1.

\subsection{Sensitivity analysis}

The criteria we used to determine favorable conditions for ice wedge cracking were whether winter 2014-2015 temperatures at the top of the southeast ice wedge cooled below $-13^{\circ} \mathrm{C}$, and whether the rate of cooling surpassed $0.1^{\circ} \mathrm{C} \mathrm{day}^{-1}$ for two days or more (Morse and Burn, 2013). The range of topographies simulated in our sensitivity analysis straddled these conditions (Table 5), with minimum temperatures at the top of the ice wedge varying from $-15.16^{\circ} \mathrm{C}$ in a polygon with rims $15 \mathrm{~cm}$ higher and a trough the same depth as our field site, to $-12.87^{\circ} \mathrm{C}$ in a polygon with rims $10 \mathrm{~cm}$ lower and a trough $40 \mathrm{~cm}$ deeper. In all cases in which temperature cooled below $-13{ }^{\circ} \mathrm{C}$, the rate of cooling was sufficient to favor cracking. Minimum winter temperature in the ice wedge increased with trough depth in almost all cases, 


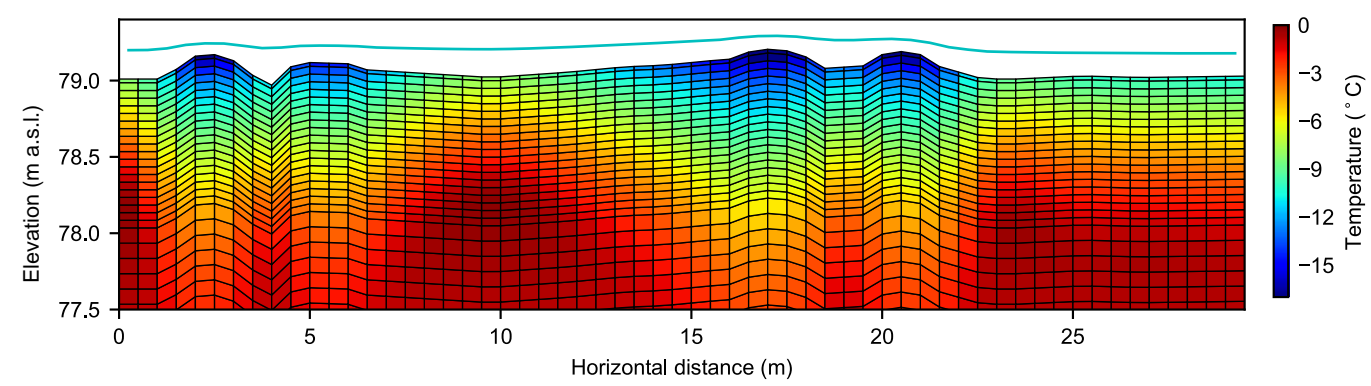

Figure 7. Snapshot of simulated snowpack surface (cyan line) and ground temperature on 24 December 2014 (vertical exaggeration $=4$ ). Only near-surface is shown; spatial domain of simulation extends to $50 \mathrm{~m}$ below the ground surface.

Table 5. Sensitivity analysis: minimum simulated temperature at top of ice wedge $\left({ }^{\circ} \mathrm{C}\right)$.

\begin{tabular}{crrrrrr}
\hline Trough & \multicolumn{6}{c}{ Rim manipulation (cm) } \\
\cline { 2 - 7 } manipulation (cm) & -10 & -5 & 0 & +5 & +10 & +15 \\
\hline 0 & -13.94 & -14.08 & -14.37 & -14.56 & -14.92 & -15.16 \\
-10 & -13.18 & -13.42 & -14.07 & -14.39 & -14.87 & -14.98 \\
-20 & -12.88 & -13.33 & -13.85 & -14.13 & -14.57 & -15.00 \\
-30 & -12.99 & -13.11 & -13.52 & -13.99 & -14.34 & -14.71 \\
-40 & -12.87 & -12.98 & -13.38 & -13.89 & -14.28 & -14.57 \\
\hline
\end{tabular}

and always decreased with rim height. Cracking was determined to be favorable in most simulations, as the ice wedge failed to cool below $-13^{\circ} \mathrm{C}$ only when rim height was less than our field site and trough depth was greater.

\section{Discussion}

\subsection{Zonation in the subsurface thermal regime at our field site}

Data from our field site demonstrated a clear pattern in which low-centered polygon rims become the coldest region of the subsurface in winter, even in a polygon with relatively modest relief. The stark seasonality of this pattern, whereby rims become colder than the centers only after snow has accumulated on the ground, is consistent with the hypothesis that most of the variation in subsurface temperatures can be explained by snow depth variation associated with microtopography. Although this finding was expected, our 2-D model using field site topography is, to our knowledge, the first physical simulation at the polygon scale to demonstrate that depth variation induced by leveling of the snowpack surface is sufficient to explain observed zonation in the subsurface thermal regime. Our confidence in the model is reinforced by the low RMSE between observed and simulated temperatures, obtained using soil physical parameters derived from core samples and a calibrated estimate of snow thermal conductivity that fits recent field measurements (Riche and Scheebeli, 2013; Domine et al., 2016).
The findings from our rank sum tests, that even relatively small rims become colder than the polygon centers in winter, and that rims fully freeze before the rest of the polygon, support the hypothesis that rims are sites of enhanced cooling in low-centered polygons, as suggested by Christiansen (2005). These findings are also consistent with data and a conceptual model presented by Morse and Burn (2014), who argued that the early completion of freeze up in the rims creates a closed hydrologic system in low-centered polygons, which drives the formation of frost blisters when the active layer is saturated. Our simulation results imply that the effects of enhanced cooling in the rims extend to adjacent regions of the subsurface, as temperature gradients throughout the active layer in early winter favor the transfer of heat from the center and the troughs toward the rims (Fig. 7). Complementing this trend, a number of physical factors underscore the potential for rims to act as preferential outlets of subsurface energy. Because the rims are the first region of the polygon to experience sub-freezing temperatures, laterally oriented thermal gradients are established very early in winter, just as large quantities of latent heat are released by phase change of soil water (from liquid to solid) in the centers and troughs. At precisely the same time, the thermal conductivity of soil in the rims also increases abruptly due to freezing. Working synergistically, these factors can deliver a considerable boost to freezing and cooling processes in subsurface regions adjacent to the rim, including the ice wedge. 


\subsection{Sensitivity of ice wedge temperatures to topography}

The key insight delivered by our sensitivity analysis is that both trough depth and rim height have substantial influence on wintertime temperatures in the ice wedge. Unsurprisingly, deeper troughs are associated with warmer ice wedge temperatures, due to increased insulation of the active layer directly above the wedge. However, perhaps less intuitively, rim height appears to hold even greater influence on the thermal regime of the ice wedge: leaving other factors constant, varying rim height across a $25 \mathrm{~cm}$ range produced up to a $2.1^{\circ} \mathrm{C}$ change in minimum ice wedge temperature, compared with $1.1^{\circ} \mathrm{C}$ of variation associated with a $40 \mathrm{~cm}$ range of trough depth (Table 5). Rims in our simulations consistently acted as preferential outlets of energy from the subsurface in winter, because in all cases, increased rim heights were associated with colder ice wedge temperatures, due to lateral heat conduction from the troughs. The relatively high sensitivity of ice wedge temperature to rim height implies that most of the cooling experienced by the ice wedge in winter occurs through the rims, rather than through the active layer of the troughs. Moreover, the proportion of cooling attributable to the rim increases with rim size, because larger rims decrease the sensitivity of ice wedge temperature to trough depth (Table 5).

Compared with the criteria determined by Morse and Burn (2013), our results suggest that this variability in ice wedge temperature may determine whether or not a crack occurs in a given winter. This conclusion is supported by prior field studies. In Svalbard, for example, Christiansen (2005) suggested that most of the cooling experienced by an ice wedge occurs through the rims, and Watanabe et al. (2017) observed that ice wedge cracking is most active in polygons with well-developed rims hosting minimal snow cover. Along the Beaufort Sea coast in northwestern Canada, it has been observed that ice wedges beneath well-developed troughs crack infrequently, presumably due to the insulation provided by increased snow cover (Mackay, 2000; Burn, 2004). These observations affirm that the effects of rim and trough morphology on the ground thermal regime at the periphery of the polygon are sufficient to change the frequency of cracking events.

One practical implication of our results is that the effects of a deep trough on cracking behavior are minimized if large rims are maintained, but become more significant as rims are destroyed. For example, in the final year of our simulations, ice wedge temperatures do not reach $-13^{\circ} \mathrm{C}$ in a polygon with rims smaller than our field site and a trough $40 \mathrm{~cm}$ lower, representing an advanced stage of thermokarst development. In contrast, ice wedge temperatures drop considerably below $-13{ }^{\circ} \mathrm{C}$ in a polygon that has equally degraded troughs, but has rims $15 \mathrm{~cm}$ higher than the field site, a form resembling the enigmatic "fortress polygons" described by Root (1978) and Mackay (2000). This finding implies that ice wedge cracking is far more favorable, and therefore more frequent, in fortress polygons as compared with high-centered polygons, despite both forms representing thermokarst trajectories (Mackay, 2000). Moreover, this mechanism could help explain the persistence of low-centered form in fortress polygons, which would be reinforced by sustained ice wedge growth.

The role of rims as preferential outlets of subsurface heat is consistent with the idea that topographic highs in ice wedge polygons cool more efficiently than depressed areas (Christiansen, 2005; Gamon et al., 2012; Watanabe et al., 2017), but conflicts with the idea previously suggested by Lachenbruch (1966), that rim development gradually suppresses ice wedge cracking by increasing snow entrapment in the troughs. It is important to acknowledge that our model does not fully negate Lachenbruch's hypothesis, as conditions not incorporated into the sensitivity analysis, such as vegetation differences between the rims and center, can also influence snow accumulation patterns and energy exchange between the ground and atmosphere (Gamon et al., 2012). Nonetheless, our results strongly suggest that, considered as an independent variable, increased rim height enhances wintertime cooling in the ice wedge.

Overall, our analysis strongly affirms the idea that the microtopography of ice wedge polygons drives considerable and systematic spatial variation in the subsurface thermal regime, which must be considered in any conceptualization of ground thermal contraction stresses (Lachenbruch, 1962, 1966; Burn, 2004; Morse and Burn, 2013; Burn and O'Neill, 2015). Regarding historical polygon development, our results support the hypothesis of Morse and Burn (2013) and Burn and O'Neill (2015) that feedbacks associated with microtopographic change are sufficient to explain the presence of secondary wedges in modern and ancient polygons, as rim destruction and trough deepening are common events across much of the tundra, and both suppress the potential for cracking. This conclusion is important for interpretation of relict ice wedge casts, because it implies that the absence of secondary ice wedges, rather than reflecting a climatic signal, may indicate that wedges grew syngenetically (i.e., in an aggrading landscape) or anti-sygenetically (in an erosive landscape). Modern wedges found in such systems are associated with only modest, or altogether absent, microtopography (Mackay, 1990, 1995; Burn and O'Neill, 2015), and surveys using ground penetrating radar in these settings confirm that secondary wedges are rare, even in polygons old enough to have been exposed to many extreme winters (Morse and Burn, 2013). In contrast, both the development of microtopography and deformation through thermokarst processes tend to be more pronounced above epigenetic ice wedges (i.e., those forming below stable ground surfaces, such as our field site). If the primary ice wedges in such settings are deactivated through a combination of rim destruction and trough deepening, a secondary wedge may form so long as thermal conditions in the center of the polygon remain favorable for 
cracking. The new wedge would be initiated by contraction stresses which had been relieved in previous winters through activity in the primary network. Cracking in the new wedge would become increasingly frequent if rims begin to develop adjacent to it, or if the troughs above the primary network continue to subside.

This same concept, that low rims and deep troughs suppress ice wedge cracking, also has important implications regarding the permanence of recent thermokarst development across the Arctic (e.g., Jorgenson et al., 2006; Liljedahl et al., 2016). It has already been emphasized that the destruction of an ice-rich transition layer at the top of the permafrost may render irreversible much of the regional-scale thermokarst observed in the past three decades (Raynolds et al., 2014). Our model indicates that changes to topography associated with ice wedge thaw compound this effect, as the development of high-centered polygon mictrotopography impedes the ability of the ice wedge to cool to temperatures favorable for cracking, even relative to scenarios with minimal microtopography (Table 5). Because of this topographic disadvantage, the ice wedges surrounding high-centered polygons should crack infrequently, and might only return to normal levels of activity if the winter climate becomes colder (or less snowy) than the conditions in which the wedges first formed. Thus, the re-establishment of rims in thermokarst terrain is unlikely should future air temperatures remain on a warming trajectory, or even if the climate stabilizes. This implies that regional scale changes to tundra hydrology (Liljedahl et al., 2012, 2016) and microbial processing of soil organic carbon (Zona et al., 2011; Wainwright et al., 2015) associated with high centered polygon development are likely to persist, once initiated, for timescales mirroring regional climate fluctuations.

\section{Conclusions}

Our analysis of observational data confirms that the microtopography of ice wedge polygons drives considerable, systematic variation in near surface ground temperatures, even in a set of polygons with relatively modest relief. This variation is most notable in winter, as subsurface cooling is most efficient beneath microtopographic highs and impeded beneath microtopographic lows. Our numerical model reveals that rims act as preferential outlets of subsurface heat in low-centered polygons, because lateral temperature gradients drive energy transfer from adjacent regions of the subsurface toward the rims in winter. Therefore, increased rim size drives colder temperatures in the ice wedge. Rim size and trough depth represent critical factors influencing whether an ice wedge becomes cold enough to crack during winter. Therefore, feedbacks between microtopographic change and subsurface temperatures can explain deactivation of the primary network and development of secondary ice wedges in modern and ancient polygons. The absence of secondary ice wedges in relict cast systems may reflect syngenetic or antisyngenetic growth, which tends to result in muted microtopography, rather than a climatic signal. Because decreased rim size and increased trough depth both suppress ice wedge cracking, development of modern thermokarst topography is likely to reduce rates of ice wedge growth, precluding the re-establishment of rims around degraded troughs.

Data availability. Data and code related to this study are available at https://doi.org/10.5281/zenodo.1284604 (Abolt et al., 2018).

Supplement. The supplement related to this article is available online at: https://doi.org/10.5194/tc-12-1957-2018-supplement.

Competing interests. The authors declare that they have no conflict of interest.

Acknowledgements. We are grateful for the support provided for this research, which included NASA's Jet Propulsion Laboratory under contract no. C021199 (Erika Podest is our Project Manager); the NASA Earth and Space Science Fellowship program, for an award to CJA; the Next Generation Ecosystem Experiments Arctic (NGEE-Arctic) project (DOE ERKP757) funded by the Office of Biological and Environmental Research in the US Department of Energy Office of Science; and Todd Caldwell and Toti Larson (Bureau of Economic Geology, The University of Texas at Austin) for lively conversation and contributions to field work. We thank the editor and two anonymous reviewers for detailed and constructive suggestions for revisions to the manuscript.

Edited by: Peter Morse

Reviewed by: two anonymous referees

\section{References}

Abolt, C. J., Young, M. H., and Caldwell, T. G.: Numerical modelling of ice-wedge polygon geomorphic transition, Permafrost Periglac., 28, 347-355, https://doi.org/10.1002/ppp.1909, 2017.

Abolt, C. J., Young, M. H., Atchley, A. L., and Harp, D. H.: Sensitivity analysis of ice wedge temperature to polygonal microtopography, Zenodo repository, https://doi.org/10.5281/zenodo.1284604, 2018.

Allard, M. and Kasper, J. N.: Temperature conditions for ice-wedge cracking: Field measurements from Salluit, northern Quebec, Proceedings of the Seventh International Conference on Permafrost, National Research Council of Canada, 5-12, 1998.

Atchley, A. L., Painter, S. L., Harp, D. R., Coon, E. T., Wilson, C. J., Liljedahl, A. K., and Romanovsky, V. E.: Using field observations to inform thermal hydrology models of permafrost dynamics with ATS (v0.83), Geosci. Model Dev., 8, 2701-2722, https://doi.org/10.5194/gmd-8-2701-2015, 2015.

Atchley, A. L., Coon, E. T., Painter, S. L., Harp, D. R., and Wilson, C.: Influences and interactions of inundation, peat, and snow 
on active layer thickness, Geophys. Res. Lett., 43, 5116-5123, https://doi.org/10.1002/2016GL068550, 2016.

Burn, C. R.: A field perspective on modelling "single-ridge" ice-wedge polygons, Permafrost Periglac., 15, 59-65, https://doi.org/10.1002/ppp.475, 2004.

Burn, C. R. and O'Neill, H. B.: Subdivision of ice-wedge polygons, western Arctic coast, Canadian Geotechnical Society, Quebec, QC, 2015.

Christiansen, H. H.: Thermal regime of ice-wedge cracking in Adventdalen, Svalbard, Permafrost Periglac., 16, 87-98, https://doi.org/10.1002/ppp.523, 2005.

Coon, E. T., David Moulton, J., and Painter, S. L.: Managing complexity in simulations of land surface and nearsurface processes, Environ. Model. Softw., 78, 134-149, https://doi.org/10.1016/j.envsoft.2015.12.017, 2016.

Domine, F., Barrere, M., and Sarrazin, D.: Seasonal evolution of the effective thermal conductivity of the snow and the soil in high Arctic herb tundra at Bylot Island, Canada, The Cryosphere, 10, 2573-2588, https://doi.org/10.5194/tc-10-2573-2016, 2016.

Dostovalov, B. N. and Popov, A. I.: Polygonal systems of icewedges and conditions of their development, Proceedings of the International Conference on Permafrost, National Academy of Sciences-National Research Council, 71-76, 1966.

Fortier, D. and Allard, M.: Frost-cracking conditions, Bylot Island, eastern Canadian Arctic archipelago, Permafrost Periglac., 16, 145-161, https://doi.org/10.1002/ppp.504, 2005.

Gamon, J. A., Kershaw, G. P., Williamson, S., and Hik, D. S.: Microtopographic patterns in an arctic baydjarakh field: do finegrain patterns enforce landscape stability?, Environ. Res. Lett., 7, 015502, https://doi.org/10.1088/1748-9326/7/1/015502, 2012.

Goodrich, L. E.: The influence of snow cover on the ground thermal regime, Can. Geotech. J., 19, 421-432, 1982.

Harp, D. R., Atchley, A. L., Painter, S. L., Coon, E. T., Wilson, C. J., Romanovsky, V. E., and Rowland, J. C.: Effect of soil property uncertainties on permafrost thaw projections: a calibration-constrained analysis, The Cryosphere, 10, 341-358, https://doi.org/10.5194/tc-10-341-2016, 2016.

Isarin, R. F. B.: Permafrost distribution and temperatures in Europe during the Younger Dryas, Permafrost Periglac., 8, 313333, 1997.

Jan, A., Coon, E. T., Painter, S. L., Garimella, R., and Moulton, J. D.: An intermediate-scale model for thermal hydrology in lowrelief permafrost-affected landscapes, Comput. Geosci., 22, 163177, https://doi.org/10.1007/s10596-017-9679-3, 2018.

Johnson, W. H.: Ice-wedge casts and relict patterned ground in central Illinois and their environmental significance, Quaternary Res., 33, 51-72, 1990.

Jorgenson, M. T. and Shur, Y.: Evolution of lakes and basins in northern Alaska and discussion of the thaw lake cycle, J. Geophys. Res., 112, F02S17, https://doi.org/10.1029/2006JF000531, 2007.

Jorgenson, M. T., Shur, Y. L., and Pullman, E. R.: Abrupt increase in permafrost degradation in Arctic Alaska, Geophys. Res. Lett., 33, https://doi.org/10.1029/2005GL024960, 2006.

Jorgenson, M. T., Kanevskiy, M., Shur, Y., Moskalenko, N., Brown, D. R. N., Wickland, K., Striegl, R., and Koch, J.: Role of ground ice dynamics and ecological feedbacks in recent ice wedge degradation and stabilization, J. Geophys. Res.-Earth, 120, 2280-2297, https://doi.org/10.1002/2015JF003602, 2015.
Kanevskiy, M., Shur, Y., Jorgenson, M. T., Ping, C. L., Michaelson, G. J., Fortier, D., Stephani, E., Dillon, M., and Tumskoy, V.: Ground ice in the upper permafrost of the Beaufort Sea coast of Alaska, Cold Reg. Sci. Technol., 85, 56-70, https://doi.org/10.1016/j.coldregions.2012.08.002, 2013.

Kokelj, S. V., Pisaric, M. F. J., and Burn, C. R.: Cessation of ice wedge development during the 20th century in spruce forests of eastern Mackenzie Delta, Northwest Territories, Canada, Can. J. Earth Sci., 44, 1503-1515, 2007.

Kokelj, S. V., Lantz, T. C., Wolfe, S. A., Kanigan, J. C., Morse, P. D., Coutts, R., Molina-Giraldo, N., and Burn, C. R.: Distribution and activity of ice wedges across the forest-tundra transition, western Arctic Canada, J. Geophys. Res.-Earth, 119, 2032-2047, https://doi.org/10.1002/2014JF003085, 2014.

Lachenbruch, A. H.: Mechanics of thermal contraction cracks and ice-wedge polygons in permafrost, Special Paper, Geological Society of America, New York, 1962.

Lachenbruch, A. H.: Contraction theory of ice-wedge polygons: A qualitative discussion, Proceedings of the International Conference on Permafrost, National Academy of Sciences-National Research Council, 63-70, 1966.

Leffingwell, E. de K.: Ground-ice wedges: The dominant form of ground-ice on the north coast of Alaska, J. Geol., 23, 635-654, 1915.

Liljedahl, A. K., Hinzman, L. D., and Schulla, J.: Ice-wedge polygon type controls low-gradient watershed-scale hydrology, Proceedings of the Tenth International Conference on Permafrost, The Northern Publisher, 2012.

Liljedahl, A. K., Boike, J., Daanen, R. P., Fedorov, A. N., Frost, G. V., Grosse, G., Hinzman, L. D., Iijma, Y., Jorgenson, J. C., Matveyeva, N., Necsoiu, M., Raynolds, M. K., Romanovsky, V. E., Schulla, J., Tape, K. D., Walker, D. A., Wilson, C. J., Yabuki, H., and Zona, D.: Pan-Arctic ice-wedge degradation in warming permafrost and its influence on tundra hydrology, Nat. Geosci., 9, 312-318, https://doi.org/10.1038/ngeo2674, 2016.

Mackay, J. R.: The direction of ice-wedge cracking in permafrost: downward or upward?, Can. J. Earth Sci., 21, 516-524, 1984.

Mackay, J. R.: Some observations on the growth and deformation of epigenetic, syngenetic, and antisyngenetic ice wedges, Permafrost Periglac., 1, 15-29, https://doi.org/10.1002/ppp.3430010104, 1990.

Mackay, J. R.: Air temperature, snow cover, creep of frozen ground, and the time of ice-wedge cracking, western Arctic coast, Can. J. Earth Sci., 30, 1720-1729, 1993.

Mackay, J. R.: Ice wedges on hillslopes and landform evolution in the late Quaternary, western Arctic coast, Canada, Can. J. Earth Sci., 32, 1093-1105, https://doi.org/10.1139/e04-031, 1995.

Mackay, J. R.: Thermally induced movements in ice-wedge polygons, western arctic coast: a long-term study, Geogr. Phys. Quatern., 54, 41-68, https://doi.org/10.7202/004846ar, 2000.

Mackay, J. R. and MacKay, D. K.: Snow cover and ground temperatures, Garry Island, NWT, Arctic, 287-296, 1974.

Morse, P. D. and Burn, C. R.: Field observations of syngenetic ice wedge polygons, outer Mackenzie Delta, western Arctic coast, Canada, J. Geophys. Res.-Earth, 118, 1320-1332, https://doi.org/10.1002/jgrf.20086, 2013.

Morse, P. D. and Burn, C. R.: Perennial frost blisters of the outer Mackenzie Delta, western Arctic coast, Canada, Earth Surf. Proc. Land., 39, 200-213, https://doi.org/10.1002/esp.3439, 2014. 
Moulton, D., Buksas, M., Pritchett-Sheats, L., Day, M., Berndt, M., Garimella, R., Hammond, G., and Meza, J.: High-level design of Amanzi, the multi-process high performance computing simulator, United States Department of Energy, 2011.

O'Neill, H. B. and Christiansen, H. H.: Detection of ice wedge cracking in permafrost using miniature accelerometers, J. Geophys. Res.-Earth, 123, 642-657, https://doi.org/10.1002/2017JF004343, 2018.

Osterkamp, T. E. and Romanovsky, V. E.: Characteristics of Changing Permafrost Temperatures in the Alaskan Arctic, USA, Arctic and Alpine Research, 28, 267-273, https://doi.org/10.2307/1552105, 1996.

Painter, S. L., Coon, E. T., Atchley, A. L., Berndt, M., Garimella, R., Moulton, J. D., Svyatskiy, D., and Wilson, C. J.: Integrated surface/subsurface permafrost thermal hydrology: Model formulation and proof-of-concept simulations, Water Resour. Res., 52, 6062-6077, https://doi.org/10.1002/2015WR018427, 2016.

Plug, L. and Werner, B.: Nonlinear dynamics of ice-wedge networks and resulting sensitivity to severe cooling events, Nature, 417, 929-933, https://doi.org/10.1038/nature00797, 2002.

Raynolds, M. K., Walker, D. A., Ambrosius, K. J., Brown, J., Everett, K. R., Kanevskiy, M., Kofinas, G. P., Romanovsky, V. E., Shur, Y., and Webber, P. J.: Cumulative geoecological effects of 62 years of infrastructure and climate change in ice-rich permafrost landscapes, Prudhoe Bay Oilfield, Alaska, Glob. Change Biol., 20, 1211-1224, https://doi.org/10.1111/gcb.12500, 2014.

Riche, F. and Schneebeli, M.: Thermal conductivity of snow measured by three independent methods and anisotropy considerations, The Cryosphere, 7, 217-227, https://doi.org/10.5194/tc-7217-2013, 2013.

Rodell, M., Houser, P. R., Jambor, U., Gottschalck, J., Mitchell, K., Meng, C.-J., Arsenault, K., Cosgrove, B., Radakovich, J., Bosilovich, M., Entin, J. K., Walker, J. P., Lohmann, D., and Toll, D.: The Global Land Data Assimilation System, B. Am. Meteorol. Soc., 85, 381-394, https://doi.org/10.1175/BAMS-85-3-381, 2004.

Romanovsky, V., Kholodov, A., Cable, W., Cohen, L., Panda, S., Muskett, R., Marchenko, S., Yoshikawa, K., and Nicolsky, D.: Network of Permafrost Observatories in North America: Temperature in deep boreholes, Arctic Data Center, data set, https://doi.org/10.18739/A26R78, 2009.

Root, J. D.: Ice-wedge polygons, Tuktoyaktuk area, NWT, Paper, Geological Survey of Canada, 1975.
Schuh, C., Frampton, A., and Christiansen, H. H.: Soil moisture redistribution and its effect on inter-annual active layer temperature and thickness variations in a dry loess terrace in Adventdalen, Svalbard, The Cryosphere, 11, 635-651, https://doi.org/10.5194/tc-11-635-2017, 2017.

Sjoberg, Y., Coon, E. T., Sannel, A. B. K., Pannetier, R., Harp, D., Frampton, A., Painter, S. L., and Lyon, S. W.: Thermal effects of groundwater flow through subarctic fens: A case study based on field observations and numerical modeling, Water Resour. Res., 52, 1591-1606, https://doi.org/10.1002/2015WR017571, 2016.

Wainwright, H. M., Dafflon, B., Smith, L. J., Hahn, M. S., Curtis, J. B., Wu, Y., Ulrich, C., Peterson, J. E., Torn, M. S., and Hubbard, S. S.: Identifying multiscale zonation and assessing the relative importance of polygon geomorphology on carbon fluxes in an Arctic tundra ecosystem, J. Geophys. Res.-Biogeo., 120, 788808, https://doi.org/10.1002/2014JG002799, 2015.

Wainwright, H. M., Liljedahl, A. K., Dafflon, B., Ulrich, C., Peterson, J. E., Gusmeroli, A., and Hubbard, S. S.: Mapping snow depth within a tundra ecosystem using multiscale observations and Bayesian methods, The Cryosphere, 11, 857-875, https://doi.org/10.5194/tc-11-857-2017, 2017.

Walker, D. A., Webber, P. J., Binnian, E. F., Everett, K. R., Lederer, N. D., Nordstrand, E. A., and Walker, M. D.: Cumulative impacts of oil fields on northern Alaskan landscapes, Science, 238, 757$761,1987$.

Walters, J. C.: Ice-wedge casts and relict patterned-ground in northeast Iowa, USA, Permafrost Periglac., 5, 269-281, 1994.

Watanabe, T., Matsuoka, N., Christiansen, H. H., and Cable, S.: Soil physical and environmental conditions controlling patterned ground variability at a continuous permafrost site, Svalbard, Permafrost Periglac., 28, 433-445, https://doi.org/10.1002/ppp.1924, 2017.

Wind, G. P.: Capillary conductivity data estimated by a simple method, in Water in the unsaturated zone: Proceedings of the Wageningen Symposium, International Association of Scientific Hydrology, 1, 181-191, 1969.

Yang, D., Goodison, B. E., Ishida, S., and Benson, C. S.: Adjustment of daily precipitation data at 10 climate stations in Alaska: Application of World Meteorological Organization intercomparison results, Water Resour. Res., 34, 241-256, 1998.

Zona, D., Lipson, D. A., Zulueta, R. C., Oberbauer, S. F., and Oechel, W. C.: Microtopographic controls on ecosystem functioning in the Arctic coastal plain, J. Geophys. Res., 116, G00I08, https://doi.org/10.1029/2009JG001241, 2011. 